\title{
Smart phone market - brand preference analysis (Huawei as an example)
}

\author{
Meng sun \\ Department of Personnel \\ Yunnan University of Finance and Economics \\ Kunming, China \\ 55658741@qq.com \\ Bingqing Ding* \\ International Business School
}

\author{
Yunnan University of Finance and Economics \\ Kunming, China \\ 1446202654@qq.com \\ Wei Zhou \\ International Business School \\ Yunnan University of Finance and Economics \\ Kunming, China \\ zw453@163.com
}

\begin{abstract}
Explosive growth in the smart phone market in recent years, the smart phone market competition is intense. Mobile phone brand, type and function rapidly increase, the price generally decline. When consumer is buying goods will evaluate the value of the commodity structure, according to the value of his thought important factors such as product quality, price and service to evaluate factors, and then select the product that consumer choice, consumers would have a preference for the brand, brand preference is one of the forms after consumers buy preferences. This paper analyzed the influence factors of domestic consumer brand preference and to the company as an example.
\end{abstract}

Keywords: the smart phone market; brand preference

\section{INTRODUCTION}

With the arrival of the mobile Internet era, popular smart phone has become a major trend in the mobile phone market. Consumers are no longer only consider the phone's appearance and basic functions who begin to pursue powerful mobile operating system and personalized social services. More and more consumers have purchased machine targeting the smart phone body. In order to meet consumer demand, the major mobile brands have launched their own smart phone series, but it can not be ignored that smart phones have both high performance and high price. Many consumers want to have a good smart phone with cheap price.

In recent years, the global mobile communications industry has developed rapidly, especially in China. At present, the Chinese mobile phone market, smart phones accounted for the high-end market. Smart phone users in China probably are between the ages of 15-50 people, especially young people mainly. This population is relatively high level of knowledge, access to the forefront of the era of science and technology, electronic products are more familiar with high demand on the network. Smart phone likes personal computers which has independent operating system. Users can download their own software, games and other third-party service provider. In addition to the smart phone call function, it also has the GPS and e-mail.
Then this article will analyze from the perspective of brand preference. Anderson according to convenienceoriented concept of empirical research, the consumer preferences were divided into two categories: the convenience-oriented and non-oriented convenience [1]. Yale defined the convenient guide as the customer wishes to pay the minimum time and effort to complete a transaction task [2]. Lancaster proposed product differentiation frame assumptions which means consumer needed not product itself, it also included energy, quality and other factors in commodities [3]. McFadden and Curim pointed out consumers through comprehensive product information, evaluation of the effectiveness of the product, compare its size, select the largest utility [4]. She researched on brand preference factors from products consumption and external factors and then proposed brand preference [5]. Ma [6], Niedrich [7] and Zhou [8] all raised the importance of brand awareness which is the foundation of brand preference. These applications of brand preference showed that brand preference in dealing with the phenomenon of consumer consumption, which is also a reason why we choose this method to analyze smart phone market.

Apart from the analyze of factors that influences the brand preference, some scholars analyze the influence of external consumption habits has acquired a lot of achievements and use the theory of brand preference to analyze other things, such as, international asset pricing have become the attention in recent years, researchers from different angles to explore it. Gomez et al. used of external consumption habits to discuss international asset pricing [9]. Verdelhan used the external consumption habits explain rates wind insurance premium [9]. There is also a lot of literature on the spending habits of funding in China, such as $\mathrm{Xu}$ and Chen constructed consumption habits pricing model based on the preferences for wealth [10-11]. Hang discussed the influence of spending habits to households saving behavior [12]. Base on that, we will continue to introduce the smart phone market based on brand preference. 
At present, Chinese smart phone market has many brands, such as Samsung, Huawei, Apple and so on. Apple accounted for most of the market share of smart phones in Chian. Due to the rapid development of positive popularity of smart phones, Huawei, ZTE, Lenovo, OPPO, Jin, cool, etc. have ushered in a new round of spring, millet, Meizu and other emerging brands rise, so the domestic smart phones occupy large part of the market share. Chinese domestic brand mobile phones proved their energy, Huawei, millet, ZTE and other brands in the market have occupied a good market share [13]. In recent years, the pattern of Chinese smart phone market will not change much, or foreign phone will occupy the main market.

Based on the literature review above and practical trends in smart phone market, this study proposes brand preference and applies it to analyze smart phone market in China. In order to do that, this paper is organized as follows: The introduction in Section 1. The basic theory of brand preference is proposed and their factors are discussed in Section 2. In Section 3, analyze the sales condition of Huawei. The paper ends with conclusions in Section 4. In Section 5, it's acknowledgement.

\section{BRAND PREFERENCE}

\section{A. The importance of brands}

It has a wide range of meaning to brand for consumer choice, marketing strategy development, because the nature of the goods and their different life cycle stages. When new product is launched, the brand's first work is to distinguish it from other products, in order to attract consumers' attention and tell them more about purchase option. It declared that very few consumers will tend to buy a smart phone only because it's brand name. Over the period of operation, the essential characteristics of the product will be known by consumers gradually.

Brand as a assurance mechanism to provide quality service and commitment to quality. This mechanism is set brand as collateral, regardless of the product (or service) is good or bad, it will be reflected in brand's reputation. Thereby it will affect smart phones' sales. To higher stage, the role of brand is to provide an intangible benefits. The intangible benefits not only based on quality, service, advanced technology and other entities, but also identity and give of status, grade and recognition. The role of the brand in the industry, where different characteristics have also be focused.

The basic function of brand is to attract attention and deliver their product information. If the product itself is relatively simple technology, or its function, quality readily identifiable, or it has developed to a mature stage, the product information for consumers has been relatively well-known. The product has sufficient experience can make a preference based on independent judgment, then the main value of the brand. It also attracts the attention of consumers or provide intangible benefits or values to enjoy the promise. Most brands are unable to achieve this level which depends on the strength of manufacturers and advertising resources. It wants to pass information about the quality, service, technology, etc., which are subject to the actual operating conditions. A simple brand decisions is useless. Similarly, if the product is under the lower unit price, or belonging to daily necessities, consumers may often be used, the level of understanding of product information will be rapidly increased.

\section{B. The influence factors of brand}

The main role of brand is to attract the attention of consumers in consumer preferences which affected by a number of objective and subjective factors, such as quality factors, prices factors, the brand image factors, brand reputation factors and so on. Then this article will analyze from the above perspective of brand preference.

\section{1) The quality factor}

When consumers in the purchase of goods the first thing is to consider the quality of selected goods or services. Quality refers to features associated with the product, practical performance and after-sales service. By measuring the consumer confidence in the product and producing a preference, brand perceived quality not only refers to products' quality, but also reflects the quality of consumer brand perception and memory. It is a belief that consumer brand, consumers pay more attention to practicality and product features, brand of symbolism is not very concerned. Therefore, when enterprises want to build brand, the first is to establish a positive brand perception of quality in the minds of consumers. After this, when the consumers see the brand, they will think the good quality and service of products.

\section{2) The price factor}

For consumers, not all consumers can afford expensive goods. Comparable to good quality of products, most consumers will choose to purchase lower-priced commodities. Due to non-professional consumer buying behavior, price and quality of some consumer goods will be linked, the price as an important measure of the value of goods and the quality of the pros and cons. They tend to choose high price of commodities, because the general price good means high quality. Sometimes consumers in order to meet their own motives, they would spend more money to buy some famous brands products which express the identity of them. It is visible for the price, different types of people in consumer have different brand preferences. However, in practice, there are many consumers rarely look at the brand, they only select the function and price of the product is not bad.

\section{3) The brand image factors}

When consumers buy goods, it is not simply the pursuit of the use values of commodities; different users pursue different value of commodities [14]. Today, consumers pay more attention to psychological and spiritual satisfaction, their hope to communicate those products and their personal understanding of consistent social image. The brand is not a symbol, but a graphic spirit, meaning carrier. Consumer brand is often a spiritual pursuit, self-expression which often related to the brand names, logos, product packaging, advertising and other factors [15].

\section{4) A good brand reputation}

Consumer have a strong sense of groups, they pay attention to the emotional connection between people and emphasis on good relationships [16]. Many consumers believe 
that brand advertising which recommend by close friends is more relatives to believe than other brand. Thus, once the brand establish a good reputation in the crowd, it is also have chance to win consumer preferences [17]. When companies build a brand, they not only should make advertisement, but also develop a good reputation by businesses and consumers, in order to make the surrounding crowd is convinced that the brand is trustworthy.

\section{5) Consumer values}

The values of consumers are a consumer society, a family or a group of objects of consumption overall rating or value orientation. It is the core structure of consumer psychology which reflects the cultural environment and cultural traditions, the consumption of the main constraints and the impact on their psychology. This effect is embodied in the evaluation of consumer goods use value, social value and cultural value. Different countries, ethnic and regional consumers have the different cultural environment and educational background, different culture will result in different ethnic character, aesthetic orientation which will result in different consumers' behavior orientation and different brand consumer preferences.

Consumers use the purchased goods, on the one hand in order to obtain its value in use, on the other hand is to pursuit of cultural values of commodities. When the value of goods contained values orientation resonate with consumers' and then the consumer will purchase the products in order to achieve the recognition of this orientation.

\section{6) The impact of different consumer groups}

Someone who belongs to the same type of consumer groups is more or less has the same characteristics. There are many commonalities in consumer psychology and consumer brand preference. According to the characteristics of consumers which will be distinguished the consumers which form a plurality of mutually different consumer groups.

\section{MOBILE PHONE BRAND ANALYSIS (HUAWEI AS AN EXAMPLE)}

\section{A. Huawei Company Profile}

Huawei Technologies headquartered is in Shenzhen City, Guangdong Province, China's production and sales of telecommunications equipment ESOP private company which was formed by the current president Ren Zhengfei in 1987 in Shenzhen China, the registered capital of the company is 21,000 yuan. Huawei is the world's largest telecommunications network solutions provider and the world's second largest telecom equipment supplier base. It also is the world's largest supplier of communications equipment, the world's fourth largest smart phone vendor and a leading global information and communications solutions provider. Huawei's products are mainly involved in a communication network switching network, transmission network, fixed wireless, wire line access networks, data communication networks and wireless terminal products, it also provide hardware, software and services for the worldwide communications operators and network owners and professional solution.
In addition, Huawei grabbed global and rapidly growing Chinese market, consumer demand for LTE phones in the $4 \mathrm{G}$ mobile phone technology has been leading more and more consumers agree. 4G LTE shipments continued to grow in Q3 quarter of 2014, Huawei LTE phone shipments accounted for more than 34\%. Among them, the main models $4 \mathrm{G}$ Huawei Ascend P7, Huawei G750, Huawei G6 and other global volume shipped over one million units. The world grows fastest $4 \mathrm{G}$ mobile phone is Huawei glory 6 , the sales in Chinese market has more than 200 million units and will be available in many countries. The market prospects of smart phone are very considerable.

The brand's global influence has increased significantly. With fast-grows of global smart phone, Huawei focus on key countries and increase investment in emerging markets. Through a series of effective brand promotion activities and football sponsorship, Huawei's consumer brand awareness and reputation are greatly improved. In the parts of Asia and Latin America, Huawei has become a local leading brand.

This means that Huawei represents of Chinese enterprises in the brand on the road which takes a special significance of the step. When Shao talked about Huawei enters Interbrand hundred list emotion, he said that become a real brand, challenged the impossible, we were pleased that Huawei did it first.

\section{B. Huawei cell phone brand strategy}

In the analysis of Huawei's success, it success is to get the customer's favor. Although Huaweis' prices higher expensive than other domestic smart phone, the products of Huawei still has a very attractive and cost-effective. The reason why there is such the result, I think Huawei Group implemented a brand strategy. For customers in the selection of goods, the price is certainly an important factor affecting their own preferences, but with the improvement of living standards in the selection of long-term use of mobile phones and other products, price factors increasing the proportion of small. In contrast, there is an increasing focus on the quality of goods, services offered, advertising promotions, and so on. Therefore, the brand strategy and its development process developed by Huawei, exactly meets the change of consumers' psychology.

Compared to other domestic mobile phone brand, Huawei phones' quality and value have always been far ahead. In terms of service, Huawei's mobile phone industry is not only a role model, but also the object of all businesses and enterprises. In advertising, Huawei is also distinctive. Phone faster updates, which can lead to business, if there is no time to pull a new generation of four consumer groups, they may lose their market so as to be out of the market. In order to reflect the performance of mobile phones, Huawei take a series of promotional videos to promote their performance. For example, when Huawei Zoran p8 propaganda, embroidery production process is reflected in the production process, at the same time reflects Huawei company's core values.

Huawei's brand strategy, so that Huawei has better quality and better services, and advertising, these factors relative to the price, it is more able to meet consumer demand preferences, so that the demand curve to the right product 
offset, although the price is higher, but it sold more than any other brand. It can be said that Huawei's brand strategy achievements of today's Huawei Group. He helped win the Huawei Group consumer preferences, has won the loyalty of consumers, and help it become a world-renowned global real positive sense of brand name.

\section{CONCLUSIONS}

If an enterprise uses the lower product prices to attract consumers, it is just a small aspect. In order to lock consumers finally and let them spend more money to buy their products, the most important is to provide high quality products and good service. You can see blindly price war will suffer, the quality and service are fundamental for business name. The product is not a concept of enterprise development, but a catalyst for enterprise development. If companies want bigger and stronger, they must set the standards of brand to themselves and they also should provide customers with what they want most. In short, companies which determined their own brand positioning can give consumers feel at home. Companies through brand planning, it is best to let the consumer like this brand at first sight.

\section{ACKNOWLEDGMENT}

This work was supported by the Science Foundation and Major Project of Educational Committee of Yunnan Province (No. 2014Z100); Applied Basic Research Programs of Yunnan Province (No. 2013FD029, and Philosophy and Social Science Foundation of Yunnan Province (Grant No. YB2015087)

\section{REFERENCES}

[1] W. Aderson, and Thom, "Identifying the convenience oriented Consumer," 1971.
[2] Y.L. Laura, and A. Venkatesh, "Toward the construct of Convenience in Consumer Research,” 1986.

[3] Y. Shang, and G. Nallcnhy, "Modeling Interdependent Customer Preference," Journal of Marking Rearch, 2002.

[4] K.J. Laneaster, "New Approach to Demand Theory," Journal of Political Economy, 1996.

[5] Y. Sha, and M. Greg, "Modeling Variation in Brand Preference: The Roles of Objective Environment and Motivating Conditions," Marketing Science, vol. 21, 2002, pp. 14-31.

[6] W.N. Ronald, and D.S. Scott, "The effects of exposure-order and market entry-information on brand preference: adual process model," Journal of the Academy of Marketing Science, 2008.

[7] J. Zhou, "Multinational brands naming strategy and its impact on Consumer Brand Preference," Southwest Jiaotong University, 2009

[8] H.F. Ma, "The analysis of brand preferences and consumer behavior Economic Perspective," China Business and Market, 2008.

[9] J. Gomez, P. Richard, F. Zapatero, "Implications of keeping-up-withjoneses behavior for the equilibrium cross section of stock returns:International evidence," The Journal of Finance, vol. 64, 2009, pp. $2703-2737$.

[10] A.A. Verdelhan, "Habit based explanation of exchange rate risk premium," The Journal of Finance, vol. 65, 2010, pp. 123- 146.

[11] X.S. Xu, .B. Chen, "CAPM based on relative wealth and habit formation," Journal of Management Sciences in China, vol. 7, 2004, pp. $1-6$.

[12] B. Hang, "Rural households' buffer-stock saving and habit formation," Economic Research Journal,vol. 44, 2009, pp. 96-105.

[13] G.H. Liu, B. Hui, and L. Guo, "Study factors of consumer brand preference," marketing guide, 2006, pp. 34-36.

[14] Z.B. Zhao, and Y. Zhi, "Chinese consumers prefer foreign brands and key factors finance forum," Empirical Study, 2009, pp. 90-95.

[15] C. Hui, "Consumers have the characteristics of supermarket own brand preferences empirical research," Dalian University of Technology, 2005.

[16] H.T. Li, "Brand Credibility to select preferences on consumer brand," Southwest Jiaotong University, 2008.

[17] Deng, "Influence of traditional cultural values of the brand personality consumer preference research," Gannan Normal University, 2013. 